Article

\title{
Destitution through "Development": A Case Study of the Laka Laka Project in Cochabamba, Bolivia
}

\author{
Avrum J. Shriar \\ Urban and Regional Planning Program, L.D. Wilder School of Government and Public Affairs, \\ Virginia Commonwealth University, 923 West Franklin Street, Richmond, VA 23284, USA; \\ E-Mail: ajshriar@vcu.edu; Tel.: +1-804-827-0788; Fax: +1-804-827-1275
}

Received: 11 August 2010; in revised form: 28 September 2010 / Accepted: 5 October 2010 / Published: 15 October 2010

\begin{abstract}
This study examined environmental and socioeconomic outcomes of a water project in rural Bolivia, and sought insights on how and why its planning was so flawed. The project destroyed an ancient, sustainable irrigation system, and replaced it with one that provides insufficient and diminishing quantities of water to many fewer people, appears to be causing land degradation and groundwater depletion, and has fueled conflicts. The study shows that even relatively small, NGO-led projects can generate significant negative impacts, and raises questions about the pressures on development agencies to charge ahead with projects, despite obvious potential for such impacts.
\end{abstract}

Keywords: irrigation; farming systems; Andes; impact assessment; international development

\section{Introduction}

International regional development initiatives have been predicated for decades on western-based value judgments - judgments about the socio-economic conditions, cultural norms, and livelihood systems that prevail in a given region or country, and as well, about the need for these to be altered or replaced. In most cases such value judgments and the prescriptions to which they have led have been rooted in modernization theory, that is, the notion that Western systems, practices, or technologies are preferable to those more commonly used in developing countries, particularly in their more traditional settings (see for example, [1-3]).

Emerging in response to such values and perspectives have been countless projects and programs designed to alter or "improve" conditions in Third World regions. All too often, however, these have 
been based on insensitivity and cultural chauvinism, and more specifically, by a failure to objectively analyze a region or country and the lifeways that prevail therein. In so many instances resource systems and technologies have been regarded as backward, unproductive, or otherwise inferior, relative to those found in more "modern" settings, such as Western Europe and North America. In addition, assessments of poverty have commonly been simplistic, leading to inappropriate strategies aimed at its alleviation.

Any consideration of "poverty", particularly in so-called "developing countries", should be based, first of all, on the recognition that the concept as generally perceived in the West, actually can consist of various conditions, not all of which are pernicious. Hence, the conditions and systems in place in a region must be explored with greater precision to assess whether an objectively negative situation truly exists, or rather, one that is simply distinct from a western model. Wolfgang Sachs [4,5] suggests that instead of relying on the rather amorphous, western label of "poverty" we should distinguish between three types of conditions, namely, frugality, destitution and scarcity.

Frugality typically exists among "cultures free from the frenzy of accumulation. The necessities of life are mostly won from subsistence production with only the smaller part being purchased on the market... Despite being in the 'low income bracket', no one goes hungry...Poverty here is a way of life maintained by a culture which recognizes and cultivates a state of sufficiency". However, such a state of self-reliance or "frugality" can only be maintained if the social system and natural resource base on which it depends remain sufficiently intact. If not, for instance because of severe environmental degradation, the result is "destitution". Sachs writes: "Along with community ties, land, forest, and water are the most important prerequisites for subsistence without money. As soon as they are taken away or destroyed, destitution lurks". Scarcity, on the other hand, is the most common form of poverty today, prevailing as it does within the money economy that has come to dominate in most world regions. In such a situation, people's "capacity to achieve through their own efforts gradually fades, while at the same time their desires, fueled by glimpses of high society, spiral toward infinity; this scissors-like effect of want is what characterizes modern poverty" [5]. Environmental degradation, therefore, can force a people from frugality to destitution and scarcity, as per Sachs's typology.

The ability of international development agencies and programs to reduce scarcity, as conceived by Sachs, clearly has been limited. A cash economy now dominates in most regions of the world, but a large proportion of the population, mainly in Asia, Africa, and Latin America, command an income that is insufficient to cover basic needs. According to the United Nations Development Program [6], about 1.4 billion people, more than 1/5 of the world's population, live on just over a dollar per day. And over 1 billion people (an estimated 1,020 million) are undernourished, more than ever before, according to the United Nations Food and Agriculture Organization [7]. Furthermore, it is apparent that many development efforts, due to the common emphasis on "modern" technologies and infrastructure, have contributed, often very directly, to moving particular regions and communities from a state of frugality to one of destitution and/or scarcity. This has resulted from negative effects of such technologies on natural resources and therefore, on traditional resource systems and patterns of subsistence.

This paper describes a case study of a development project completed in the late 1990s in a rural region of Cochabamba department, Bolivia (Figure 1). The project's main goal was to provide irrigation water to smallholders within an area of about 900 ha, as well as potable water to a nearby 
community, called Tarata. As discussed below, the project was fraught with many problems; it created a situation which, by most accounts, is considerably worse than that which existed in the area beforehand. Particularly disturbing is the fact that most if not all of the problems and issues the project has led to should have been foreseen. Some of these could have been mitigated but others likely would have emerged regardless. Essentially this project has had the effect of moving the majority of its so-called beneficiaries toward a state of destitution and scarcity from a state of "frugality", as defined by Sachs. A key question that presents itself, therefore, is why such a flawed project was approved to begin with.

Figure 1. The study area.

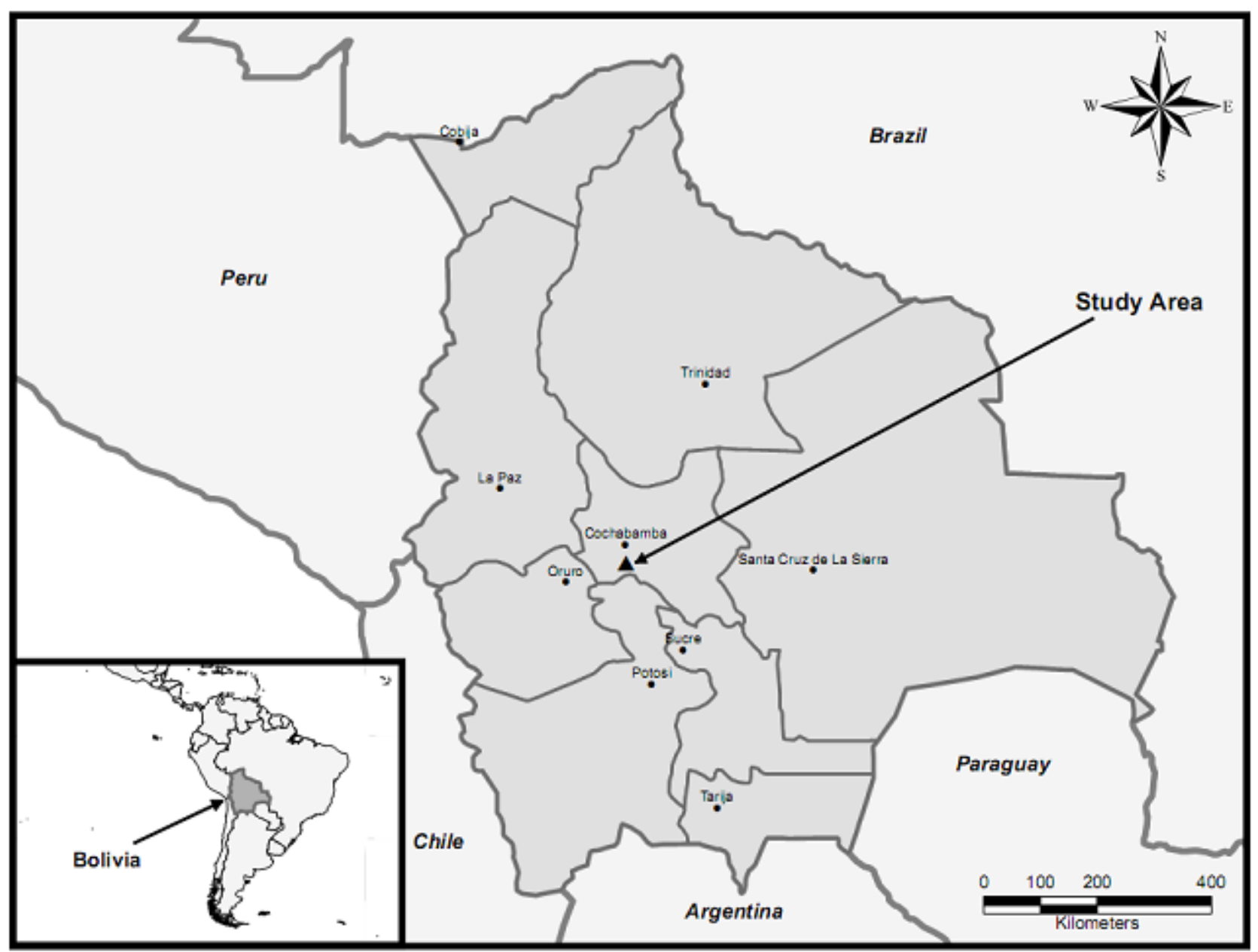

The main purpose of this study was to examine the principal socioeconomic and environmental impacts of the project, particularly with regard to the farming system changes and challenges that have emerged in the irrigated zone. This paper describes the findings in this regard and considers some factors that may have led those involved to proceed with a project that had such obvious potential for negative outcomes. It also highlights some implications that emerge from the findings.

The research involved, first, a review of literature about the project, other similar initiatives, and about the target communities and region. More importantly, fieldwork was undertaken in April 1992 and February 1995 while the project was being implemented, and again in May and June, 2005, about eight years after the project was fully completed. During the 2005 fieldwork I held one or more discussions 
with about 10 professionals familiar with the project, including some who serve or served as project technical staff. I also had numerous informal conversations and conducted 25 semi-structured interviews with farmers and other householders in the project area. The fieldwork in the 1990s was undertaken while I served as a consultant on the project for the Canadian International Development Agency (CIDA), which was its main sponsor. Project execution, however, was carried out by Club 2/3, a Montreal-based NGO in conjunction with the Centro de Investigación y Desarrollo Regional (CIDRE), a Bolivian NGO headquartered in the nearby city of Cochabamba. However, CIDRE's involvement in the project was terminated in 1995 due to "diverse misunderstandings" ("mésententes diverses" in French) relating to the myriad problems it was facing, according to the newly-appointed CIDA project officer at the time [8]. Additional engineering and equipment support was provided by the Regional Development Corporation of Cochabamba (Corporación Regional de Desarrollo de CochabambaCORDECO), a local government agency that since has been subsumed within the prefecture of Cochabamba department.

\section{The Area and Its Farming Systems}

The Laka Laka project was implemented in the municipalities of Tarata and Arbieto, two of the four municipalities that comprise the province of Esteban Arze, located in the south-central section of Bolivia's Cochabamba Department (Figure 1). The project's irrigation zone, which formed the main focus of this study, lies mainly within Arbieto municipality, at approximately $17^{\circ} 53^{\prime}$ south latitude and $16^{\circ} 15^{\prime}$ west longitude, at an elevation of about $2700 \mathrm{~m}$. The irrigation zone, often referred to locally as the abanico (which means fan in Spanish) covers most of an alluvial fan located at the base of the Calicanto River (referred to as the Wasamayu River within the abanico), where it flows into the Valle Alto or "High Valley" region of Cochabamba Department. The Valle Alto, which geologically is a graben, has been of regional agricultural importance for thousands of years and may have been one of the earliest locations of irrigated farming in the Americas [9].

The irrigation zone of the abanico is divided geographically and organizationally into sections known as suyus; these also formed the organizational basis of the traditional irrigation system before the project. There are six main sections (suyus mayores) which are further subdivided into smaller areas (suyus menores). All of the suyus mayores lie within Arbieto municipality, with the exception of one 22 ha suyu called Cabecera, located within Tarata.

Precipitation in the irrigation zone is about $42 \mathrm{~cm}$ annually, based on data from the nearby San Benito meteorological station [10]. However, other reports [11,12] provide higher rainfall figures, up to about $48 \mathrm{~cm}$ annually. Most of the rain falls between November and March, particularly during the peak summer months of December, January and February. Little or no precipitation occurs during the winter months of June, July, and August. Based on data from San Benito, mean daily maximum temperature varies little throughout the year $\left(23{ }^{\circ} \mathrm{C}-26{ }^{\circ} \mathrm{C}\right)$ but mean minimum temperatures drop considerably during the winter, from $10.2{ }^{\circ} \mathrm{C}$ in January (summer) to $-1.4{ }^{\circ} \mathrm{C}$ and $-1.5{ }^{\circ} \mathrm{C}$ in the winter months of June and July, respectively [11]. The area's most important agricultural soils are described as sandy and clayey in texture and relatively fertile [13].

According to census data the 2001 population of Arbieto and Tarata municipalities amounted to 9,438 and 8,715, respectively, while that of the province overall (Esteban Arze) was 31,997 [14]. 
Population density in the province stands at 25.74 per $\mathrm{km}^{2}$ and its population reportedly has remained static since 1976, growing only $0.16 \%$ compared to the national growth rate of $2.75 \%$ ([11], p. 18). Most of the population speaks Quechua and Spanish but many speak only Quechua. Average annual income for the province of Esteban Arze (in 1994) was US\$637 but only US\$577 in rural areas, according to a study by the United Nations Development Program (UNDP) and CORDECO [15].

During the 1990s there was substantial out-migration from this area, and from the province overall. The main destinations were Cercado Province, which contains the city of Cochabamba, and Chapare Province, the semi-tropical, northern section of the department of Cochabamaba, where coca is among the principal crops. Some also have migrated, mostly on a temporary basis, to Santa Cruz department in Bolivia's eastern lowlands, and for more extended periods to other countries, mainly Argentina, Israel, and the USA. However, the economic downturn in Argentina in the early 2000s reduced the attractiveness of that country and drove many Bolivians home or elsewhere. The tendency to migrate on a seasonal or extended basis is a common livelihood strategy in this part of the Andes, as Zimmerer [16,17] also has found in nearby communities (e.g., Pampa Churigua) located within the watershed of the Rio Calicanto.

Apart from Arbieto and Tarata, the Calicanto's $64 \mathrm{~km}^{2}$ watershed can be seen as an important area in relation to the Laka Laka project, as it drains into the Laka Laka reservoir. As will be discussed further below, land degradation in the watershed has led to rapid sedimentation of the reservoir, drastically reducing the amount of time it will be able to store water.

In examining the farming systems and strategies in the irrigated zone, it is important to consider the differences between those that prevailed before and after implementation of the Laka Laka project. As will be clear from the following description, many aspects of local farming strategy as well as the conditions and processes on which it is based, have changed as a result of the project.

Most landholdings in the irrigation zone remain between 1 and 2 ha in size, but some are as large as 10 ha. Among the 25 farmers interviewed, 15 had holdings that were divided into two or three plots, rather than just one, and in some cases these plots were located beyond the irrigation zone of the alluvial fan. The main crops include potato, maize, alfalfa (as livestock feed), and wheat. Other crops include peas, barley, haba (Lima) beans (Phaseolus lunata), and onion. Some of the crops, such as haba beans, peas, and alfalfa tend to be grown in the more naturally humid sections of the area, such as near the shallow reservoir (Angostura) located just north of the irrigation zone at the base of the alluvial fan. Alfalfa is a perennial legume, but two harvests per year of annual crops can usually be obtained in the more humid sections without irrigation. Commercial peach production has grown in importance since the completion of the project. As of 2005, some 200 ha had been planted in the irrigated zone, about ten times the area that was dedicated to this crop before the project. Most of the households have some livestock, such as cows, sheep, goats, and asses.

Soils are plowed using oxen or tractors, with the latter normally obtained as a hired service at the rate (in 2005) of about 70 bolivianos (B) per hour. (At the time of the fieldwork in 2005 the exchange rate was $8.1 \mathrm{~B}=\mathrm{US} \$ 1.00$.) Plowing is now conducted after the first irrigation cycle of the season, and again, a bit later, just before planting. Some also plow their fields after harvesting to incorporate crop residues and weeds, and to help maintain soil permeability.

Wheat and barley are planted in November or December, and harvested in May; this also was the case before the project. Potato is planted between July and September, and harvested between January 
and March, depending on the variety. Maize is planted September to November, but as early as August for the Choclero variety. Production extends until April or May for most varieties, but the Choclero's growing season extends only through December. Haba bean is planted in September and harvested late February, but the Mishka (off-season) planting runs between June and October. Onions are planted in July or August and harvested November or December. Peas are produced between September and February but a green type (Arveja verde) is raised between July and the end of November [10].

In the project's irrigated zone, maize and potato, often grown in rotation, were the principal crops before the Laka Laka project. In any given year, about 700 ha were cultivated within this area of 910 ha for at least one cropping cycle, with the remainder lying fallow. Use of fertilizer was almost non-existent, apart from some manure applications to the potato crop.

The reason for the minimal reliance on fertilizer, despite relatively intensive cultivation patterns, can be found in the traditional irrigation system that prevailed in the area before the Laka Laka project. Commonly referred to in the central Andes as the lameo or may'kas technique $[18,19]$, this system relies on flood irrigation in which sediment-rich river water is directed from a main river channel into natural distributaries (often fortified and maintained by water users) as well as man-made, earthen (unlined) canals, and eventually onto farmers' plots through openings or inlets called bocatomas. Furrows within the plot help distribute the water evenly over the land. In some cases, farmers build small dykes of mud and peat around their fields to contain the water, allowing it to gradually percolate and deposit the mineral and organic material that it carries. These dykes, usually $30 \mathrm{~cm}$ high but sometimes higher, help build up the thickness of the soil and thus the height of the plot. On average a $10 \mathrm{~cm}$ layer is deposited on the plot in this way, but this depends on discharge levels, the length of time the muddy water is diverted to the plot, and the plot's location relative to the river or a canal [19]. At the lower end of each field excess water is drained through cuts that are made in the dykes. These help ensure that a maximum water level of about $12-15 \mathrm{~cm}$ is achieved. Eventually the field inlets are blocked off so that the soil is drained over the course of about one month. The plots are then prepared for planting, which may involve mixing the new sediment with the existing soil, and with manure.

The technique reportedly is used in one form or another in a number of areas of highland Bolivia, including Oruro [18,20] and in the Arque River valley near the village of Capinota [19], which also is in Cochabamba department. The lameo system also continues to be used in the Laka Laka project area, but in a modified, short-term, and down-scaled format, as discussed below.

At Capinota the lameo strategy supports a commercial, intensive agricultural system used by more than 200 farmers on about 288 ha, wherein no fallowing is necessary. The technique is carried out every 1-3 years, mainly on fields on which potato is grown. The canals and bocatomas are maintained communally by farmers organized in groups within particular sections of the irrigated area. The farmers use the system to achieve several goals, namely to condition their soils, improve their texture, reduce salinization, and in some cases, to build up the height of their plots relative to the river water level. The latter can get very high at flood stage, particularly after years in which a large amount of sediment has been deposited in nearby sections of the main channel. It therefore constitutes a low cost, low investment system that relies only on local labor and materials, while helping maintain soil depth and height, enhancing fertility and moisture retention, and limiting nematode problems as well as the build up of mineral salts [19]. 
With the "modern" irrigation infrastructure that has effectively replaced the traditional system in the Laka Laka project area, the water is used for peach, maize, potato, and sometimes alfalfa. Wheat, peas, and haba beans are grown mainly on rainfed plots in areas with more humid soils. However, as explained below, the irrigated area is now much smaller than it was before the Laka Laka project, when local people relied exclusively on the lameo system.

\section{The Laka Laka Project and Its Impacts}

The idea of a water resources project of this type near Tarata had been toyed with since the early 1940s if not earlier, but the first detailed feasibility and design studies were not undertaken until the 1980s. These were conducted by the Centro de Investigación y Desarrollo Regional (CIDRE), the Cochabamba-based NGO, and the Corporación Regional de Desarrollo de Cochabamba (CORDECO), the departmental agency, following the signing of a 1977 cooperation agreement between the governments of Bolivia and Canada. In 1984 CIDRE completed a report on the province of Esteban Arze which extolled the virtues of a project of this type for the development of the region [21]. By 1986 a preliminary design for the dam had been prepared, and a promotional committee for the project had been formed. The latter consisted of representatives from the Cochabamba departmental government, local institutions, the Tarata mayor's office, peasant organizations, and others interested in the project's realization. More detailed feasibility studies subsequently were undertaken and presented to Club 2/3, a Montreal-based NGO, with a view to securing international financial and technical support for the project. Requests to CIDA led the agency to formally agree in June 1989 to fund the project, following a favorable evaluation of its technical and economic attributes by Groupe AFH International, CIDA-hired consultants. The agreement called for Club 2/3 to work with CIDRE as a local "partner" to implement the project in two phases [21], as described below. A study explicitly aimed at potential environmental impacts was never conducted prior to project implementation.

The involvement of CIDRE and CORDECO, and the broader effort to build up smaller local institutions to manage water supply and irrigation (see below), were entirely consistent with the 1980s' neoliberal emphases on reducing the role of the state and on decentralizing government [22]. Similarly, the project's heavy reliance and focus on NGOs of various kinds was representative of a broader movement in development and environmental management circles that intensified in the late 1980s [23,24], and that remains in place currently. Zimmerer ([24], p. 162) points out that by the early 1990s several hundred projects in community based natural resource management had been initiated in the Cochabamba region alone.

The main objective of the Laka Laka project, as outlined in CIDA project documents, was to improve living conditions for the urban and rural populations in the Tarata area through the following mechanisms:

(1) Potable water supply for residents of Tarata (613 households in the early 1990s).

(2) Provision of irrigation water for the farmers (840 households in the early 1990s) who had rights to water under the traditional flood irrigation system that prevailed prior to the project. Most of these farmers (the irrigators or regantes) own plots within the abanico area (911 ha), the alluvial fan at the base of the Calicanto River. The plan was to provide each household with a maximum of 10 acciones, supposedly enough to irrigate five arrobadas (1.81 ha). 
Each acción thus consists of an amount of water needed to irrigate $1 / 2$ arrobada (0.18 ha). The new irrigation system, it was assumed, would enable production of two crop cycles per year, rather than one, for all project beneficiaries.

(3) Steps aimed at encouraging a long-term process of agricultural development in the area.

The first phase (1989-1992) involved construction of the main project infrastructure, including a $32 \mathrm{~m}$ high dam and reservoir with a design capacity of 2.7 million $\mathrm{m}^{3}$, the primary irrigation canal (about $4 \mathrm{~km}$ in length) with a capacity of $560 \mathrm{~L} / \mathrm{s}$, and infrastructure for filtering and storing potable water for the community of Tarata. One tenth of the water stored in the reservoir (but $5 \%$ of its annual yield) was to be destined for Tarata's domestic supply. A slow sand filter system with a capacity of 12 liters per second was developed to treat the water, which would then be stored in a tank with a 300,000 liter capacity [21]. The cost of this first phase was expected to amount to 3,850,000 Canadian dollars (C\$), which was to include C\$700,000 of local contributions, but the portion covered by CIDA ended up totaling more that $C \$ 3,766,000$ [25]. Local people in the project area also made significant contributions through their labor, which amounted to 29,540 person-days by the "rural" inhabitants (those with land in the irrigation zone) and 17,802 person-days by the "urban" dwellers of the town of Tarata. This labor was supplied for free or paid for by the project beneficiaries; for example, among the rural households, 15 person-days of labor was required (along with a fee of US\$5.33) in exchange for each acción of water-supposedly enough, as noted, to irrigate $1 / 2$ arrobada or 0.18 ha [15].

The second phase, implemented between 1992 and 1997, led to the completion of the secondary irrigation canals and construction of the potable water distribution network. In addition, it involved training and institutional development aimed at managing and maintaining the project infrastructure, as well as various agricultural development and diversification initiatives, supported through the establishment of an agricultural development center. All project infrastructure was formally handed over to the Asociación de Regantes del Complejo Multiple Laka Laka (the irrigators' association) and to the Servicio de Agua Potable y Alcantarillado-SEAPA-Tarata (the town's water supply agency), in 1997. The budget for Phase II of the project was revised at various points, but amounted to C $\$ 4,347,944$ by late 1994 [26]. Thus, the total overall cost of the project was over C\$8 million.

As the mayor of Arbieto (and a member of the irrigators' association) pointed out [27], the project has enabled many farmers to plant more crops earlier or in the off-season. Several varieties of haba beans, peas, maize and potato, for example, can now be planted earlier, for instance at the end of July. Previously, only some crops were planted in September, at least on fields in fallow that held sufficient moisture to support crops until the onset of the rainy season in November. As well, the project has spurred, as noted earlier, a much larger acreage of fruit trees, mainly peach, in the area.

However, as the project was being implemented it became clear that a number of problems were likely to offset, if not eliminate, the anticipated benefits. To begin, the sedimentation rates from the Rio Calicanto watershed were never calculated in any systematic way, at least not until the dam was already constructed and the first phase of the project was complete. For reasons that are entirely unclear, the degree of soil erosion in the upper watershed was insufficiently assessed and the resulting effect in terms of reservoir sedimentation has proven to have numerous unfortunate consequences. First of all, it made it impossible to use the water as the source of potable water for the town of Tarata. 
The filtration system that was installed simply could not handle the high concentration of sediment in the water. In the late 1990s, therefore, the town's water authority, SEAPA, decided to drill two large wells to meet domestic water supply needs; this was covered not through the project, but rather, with government funds. The community also draws some of its water by pipe from the Loro Huachana River, a tributary of the Calicanto.

Second, the sedimentation process is not-so-gradually reducing the reservoir's capacity to store water. The assumption of the executing agencies before and during the reservoir's construction was that it would provide water for many decades to come-100 years, according to Flierman et al. ([11], p. 37). However, my first visit to the project area in 1992 led me to question this assumption, based merely on my observation of the degraded environmental conditions in the watershed. I subsequently spoke with the University of Wisconsin geography professor, Karl Zimmerer [28], who had done considerable field work in the area; he reckoned that the reservoir would be unusable within as little as ten years, based on his fairly cursory study of erosion in the Calicanto watershed [29]. I eventually convinced CIDA to commission a more detailed study of erosion and sedimentation in the reservoir's watershed, and of potential mitigation measures. That study, by Northwest Hydraulic, a Vancouver-based consulting firm [30], estimated remaining storage capacity at the time to

be $2,347,000 \mathrm{~m}^{3}$, with annual sedimentation rates on the order of $110,000 \mathrm{~m}^{3}$. It also concluded that in the absence of steps to remove sediment from the reservoir and/or reduce erosion in its watershed, the useful life of the facility would be reached by 2001 ! By this date storage capacity would be down to an estimated 1.5 million $\mathrm{m}^{3}$, a volume assumed by Club 2/3 staff to be the minimum needed for viable dry season irrigation. Moreover, the consultants reckoned that none of the available options for extending the reservoir's useful life, such as flushing, dredging, dam design changes, and watershed protection measures would be feasible, for economic and/or technical reasons [30]. Achieving significant and sustainable results through a soil conservation program in the watershed clearly would be very difficult, due to widespread deforestation in Cochabamba department in the 20th century [31], and to complex socio-environmental and livelihood dynamics among households within the river basin that have contributed to its degradation in recent decades [16,30]. One key factor, as determined by Zimmerer [16], has been the high degree of off-farm employment for extended periods, resulting in shortages of labor needed for soil conservation practices that were traditionally followed.

Subsequent to the Northwest Hydraulic study [30], however, actions were taken to enable at least some flushing of sediment through two outlets in the dam, including one $(1.8 \mathrm{~m} \times 1.8 \mathrm{~m})$ that was constructed for this purpose during Phase II of the project. However, the ongoing efforts to flush sediment through the dam at the beginning of each rainy season (e.g., November-December) have been of only limited effectiveness [32] and thus the reservoir continues to fill with sediment, albeit at a somewhat slower rate than that assumed by Northwest Hydraulic [30]. The initial capacity of the reservoir, as designed, was 2.7 million $\mathrm{m}^{3}$, but $25 \%$ of its capacity was lost by the end of the $1990 \mathrm{~s}$, after only eight years of operation [32], and by 2005 it had decreased by at least $40 \%$, according to a researcher at the Water Center (Centro Agua) at the Universidad Mayor de San Simon in Cochabamba [33]. Thus the storage capacity (as of this writing in 2009) is already below the 1.5 million $\mathrm{m}^{3}$ level that was deemed to be adequate for viable dry season irrigation. 
The declining availability of surface water likely will intensify disputes over water among those with irrigation rights. Instead of irrigating an area of 900 ha as the project envisioned, the area serviced with irrigation by 2005 amounted to between 450 ha and 500 ha [34,35]. However, the plots within this area typically receive only 3-4 waterings ("largadas") and some even less depending on their location within the canal network. Furthermore, according to an agronomist who is the former technical director of the Irrigators' Association [35], the amount of water available in the mid-2000s was in fact only sufficient for adequately irrigating some 200-250 ha. Before the project, roughly 700 ha within the abanico were irrigated in any given year, as about 200 ha lay in fallow. Not surprisingly, only four of the 25 farmers interviewed $(16 \%)$ said they currently receive enough water and all but three (88\%) reported that their crops received more water before the project.

Another important impact, also related to the reservoir sedimentation, is land degradation, stemming from the fact that most of the water used for irrigation no longer is laden with sediment, as it was under the traditional system. Most of the sediment gets trapped behind the dam, rather than being carried downstream and eventually onto farmers' fields. Therefore, soil fertility is no longer enhanced naturally through regular deposition of alluvium, at least not to the same degree.

Some sediment is received through water released from the dam for a few weeks at the beginning of the rainy season, when an effort is made to flush some of the collected sediment in the reservoir. This is the only time of the year when some farmers in the area can and do rely on what can be considered a relic of the traditional lameo system. In parts of the abanico area they continue to jointly maintain traditional canals that enable them to direct the mud and sediment-laden water to sections of their land, usually fallow plots or those on which maize stocks are strong enough to resist damage from an onslaught of mud and water. Once the outlets are closed, of course, the water (and most of the sediment therein) accumulates in the reservoir for the remainder of the rainy season. Only months later, during the dry season (e.g., April to November) is the water released from the reservoir into the primary and secondary canals as per the irrigation schedule, but at this point it contains very little sediment, relatively speaking.

As a result of this decreased availability of sediment and its fertility enhancing effect, virtually every farmer I spoke with reported a decline in cereal yields. The mayor of Arbieto, also a member of the irrigators' association [27], and the agronomist, Cespedes [36], both estimated that cereal yields are down an average of $50 \%$ compared to the pre-project period. They also maintain that pest damage has become a bigger issue, perhaps due to weaker, malnourished plants. Only one of the 25 farmers interviewed indicated that he used chemical fertilizer before the project but seven claimed to use it now. However, many emphasized that reliance on chemical fertilizer or large amounts of manure is now essential to obtain a decent harvest; this was not the case beforehand, when only limited amounts of manure or none at all was needed, depending on the crop in question. Many farmers indicated that due to lower productivity it is not even feasible to try to obtain two crops per year from a given plot. All but three of the interviewed farmers ( $88 \%$ ) said the productivity of the land has declined, and $84 \%$ reported that they cultivated more land before the project.

With regard to land degradation it is also worth noting that the irrigation component of the project was planned and developed without a drainage system. Therefore, soil salinization may emerge as a problem on the plots that receive irrigation water through the new irrigation network, or from wells. Interestingly, almost half of the farmers interviewed (44\%) indicated that they are seeing some buildup 
of salt on their plots, which in some cases they attributed (erroneously) to saltier irrigation water delivered through the new system. Of course, if in fact the number of years over which canal irrigation is possible proves to be quite limited due to sedimentation of the reservoir, such problems may never have time to develop to a significant degree, except on plots using well water.

With the declining availability of irrigation water from the reservoir many farmers have been compelled to turn to groundwater sources to meet their production needs. This can be expensive, however, given the cost of well digging and of powering pumps to get the groundwater to the crops. In any case, the water table in the abanico has fallen considerably, and should continue to do so. Farmers reported that their existing wells, used previously for domestic purposes exclusively, were sufficiently deep at $12 \mathrm{~m}$, but now must be deepened to $30 \mathrm{~m}$ [35]. It is probable that with the trapping of most of the river's discharge within the reservoir, and thus limited flood waters reaching the alluvial fan of the abanico, the extent of groundwater recharge is much lower than it was before the dam was built. Alluvial fans, almost invariably, are important zones of groundwater recharge $[37,38]$.

As noted earlier, residents of Tarata were never able to use the reservoir water for domestic supply because its sediment content was excessive for the filtration system installed by the project. However, people in the town, like their counterparts in the abanico, had put in a significant amount of free labor on the project, and were receiving no tangible benefit in return. In recent years, therefore, Tarata residents have clandestinely siphoned water from the primary canal to use for watering their homegardens. This led to significant conflicts between Tarata residents and SEAPA, on the one hand, and on the other, the members of the Asociación de Regantes (the irrigators' association), who live mainly in the abanico area of neighboring Arbieto municipality [11,39].

The conflict stemmed in large part from a failure of project planners to define, before project completion, "acceptable" domestic water uses. The initial water sharing agreement between SEAPA and the Asociación de Regantes did not specify how the water allocated for Tarata's residents could or could not be used. Since the project, the number and size of homegardens in Tarata have increased, and these urban gardeners, some of whom have become quite commercialized, with plots as large as 2 ha, have formed an association, AGROTAR. Members buy water from SEAPA but some of them reportedly live beyond the town's boundaries and never even worked on the dam's construction, a supposed prerequisite for receiving any of this water supply [39]. At the time of the 2005 fieldwork, an effort was being made to work out an agreement and address the conflict through the formation of a committee, with members from SEAPA and the Asociación de Regantes. The agreement was to address the quantity of water to be used by SEAPA and the Tarata residents, installation of a water meter for monitoring purposes, transfers to neighboring watersheds, and other such concerns [34].

Interpersonal rivalries and divisions also have emerged among the irrigators of the abanico. These stem from the feeling by some that others are receiving more than their fair share of the water distributed through the canal network. Many of the interviewees complained that those with plots at the end of each suyu network, i.e., "tail-enders" in irrigation parlance, are receiving less. Others claimed that those with peach orchards are effectively in control of water distribution, and thus their plots receive top priority, for example, in the scheduling of water releases through the network.

The agricultural station established through the project was meant to be a source of information, expertise, equipment, and even financial support for farmers in the irrigators' association, through a revolving credit fund. One of CIDA's consultants [40] suggested that the agricultural station would be 
staffed by two agronomists, four agricultural technicians, and the equipment necessary to assist the association farmers. However, by 2005 it featured only three paid staff members - a secretary, a night watchman, and an operador who works only during the irrigation season to operate the dam infrastructure. According to the current secretary [41] other staff positions were terminated because of budget constraints. Also, the station's tractor and other vehicles and equipment were sold at some point but nobody knows what happened to the proceeds from the sale. The current president of the irrigators' association [34] claims also that the $\$ 26,000$ that was held within a revolving fund to be used for loans to association members is missing. He reports that when he took over the job within the previous year, the station accounts amounted to just US\$400 and three months' worth of back pay was due to its employees.

\section{Conclusions and Discussion}

The Laka Laka project can be viewed as having been an outright failure in virtually every respect. It destroyed a traditional and presumably sustainable irrigation system that had been used for thousands of years (see below). In its stead it created a "modern" storage-based system that simplistically was presumed would be an improvement for the area, but which in reality provides diminishing amounts of water to many fewer farmers within a significantly smaller irrigated area. The project also has posed an enormous challenge to the sustainability and self-reliance that were inherent features of the local farming systems, as plots in the irrigation zone now receive only a fraction of the natural fertilizer that came with the sediment-rich water directed to them via the traditional flood irrigation system. Moreover, the damming of the Calicanto River has caused a substantial lowering of the water table in the abanico irrigation zone. This of course has made it harder for householders there to obtain groundwater for domestic purposes or to meet their irrigation requirements, which no longer are adequately met through surface water sources, thanks to the project. The goals of improving health conditions in Tarata through potable water supply and sanitation were not achieved, at least not through the project, as the installed water filtration system never worked and a sewage disposal or treatment system was never even planned as a project component. In addition, the project created disputes and conflicts within and among communities in the area that were supposed to be the project's "beneficiaries".

As with many projects, even ones carried out by NGOs that fancy themselves to be grass-roots and in touch with the needs of the poor, the Laka Laka initiative was actually conducive to benefiting people with existing advantages over others, and of harming the less fortunate within the area. Benefits have accrued (or at least were meant to accrue) to (a) those who could afford to provide on their own, or pay for, the construction labor (15 person-days per acción of water) that was required of project beneficiaries; (b) those able to afford the investments needed to benefit from the new irrigation system, for example to establish peach tree orchards or purchase chemical fertilizer; (c) those with plots in locations within a given suyu that receive canal water first; and (d) those who can afford to cover the costs of digging new or deeper wells, and of pumps, to ensure continued access to water (from the ground) for domestic uses and for irrigation. Therefore, it is likely that the project has served to enhance the division of wealth and power in the communities of the abanico. 
By ruining the traditional irrigation system, the project has essentially spurred a transition, in the words of Sachs [4,5], toward "destitution" from a situation of "frugality". The latter was made possible through the very efficient and seemingly sustainable agricultural system which manifested a clever adaptation to local hydrologic and geomorphic conditions. Apparently, the logic and benefits of the traditional irrigation system were never sufficiently understood or investigated. Early assumptions, dating back to the 1940s, that a dam would be a useful project for the area were never critically examined. As recently as 1993, Club 2/3 continued to assume that a shortage of water was the key factor limiting socioeconomic development in the area. One of the organization's news bulletins from that year [42] states that "The living conditions of the villagers and peasants of Tarata could be improved without a doubt, if only they had access to this vital substance that is water". (Translated from French by the author). Furthermore, there is no evidence that other possible development interventions or forms of assistance were given much consideration.

The destruction of the traditional irrigation system as a result of the project is especially disconcerting when one learns that it was truly ancient, sustaining local people for millennia. Studies of the sedimentology and geomorphology in the alluvial fan area indicate that a system of floodwater irrigation, similar to the one used until the dam was built, had been used in the project area since about 3500 B.P. [43].

It is hard to believe that the project's many potential impacts were not considered in advance, given the involvement of numerous supposed experts in engineering, rural development, agronomy, and other relevant fields. If anybody had bothered to investigate, for example, they would have encountered ample evidence of the advantages of traditional "indigenous" irrigation systems over larger "industrial" systems. Such evidence would have or should have led to a reconsideration of the project as initially conceived. As pointed out by Mabry and Cleveland ([44], p. 244), much available information "casts doubt upon the conventional wisdom that yields are stabilized through industrialization of irrigation..." In contrast, evidence for the sustainability, ingenuity, and efficiency of traditional irrigation systems lies in the fact that many have been used continuously for hundreds and even thousands of years, here in the Andes [45,46] but as well, in Africa [47], Iran [48], Sri Lanka [49], Bali [50], the southwest USA [51] and many other locations [52,53]. Mabry ([54], p. 4) notes that the "most common and enduring irrigation systems...are small, locally built, farmer managed, and adapted to a wide variety of environments". Unfortunately, "development planners have typically assumed that centralized management is more efficient, and hydraulic engineers have tended to think that bigger is better". However, ethnographic and archaeological evidence makes it "clear that large, centralized irrigation systems are relatively rare, short-lived, and limited to a narrow range of settings" ([54], p. 4).

Admittedly, the new Laka Laka irrigation system cannot be viewed as particularly large, designed, as it was, to serve an area of about 900 ha. However, as Adams and Anderson ([47], pp. 533-534) have shown, even small scale irrigation schemes, commonly pursued "as an antidote to the visible failure of 'large scale' schemes...", may nevertheless represent "thoughtless, bureaucratic large scale development in little chunks". The main issue, then, is not one of scale but rather, of failing to adequately examine and understand the prevailing agroecological and biophysical conditions in a given region, as well as community adaptations thereto. 
In essence, virtually all of the problems that have emerged with the Laka Laka project, as described in the preceding pages, could have been and should have been anticipated before it was designed and approved. Not uncommonly, insufficient time was taken to plan and reflect on the area's issues, needs, possible project impacts, likely winners and losers, and other essential matters. As a junior consultant who was just a few years out of a master's program in Environmental Studies, I was first hired to travel to Bolivia and evaluate the project from an environmental standpoint in 1992. This was at the end of Phase I and thus well after the project design had been finalized and even after the main infrastructure components, including the dam, had been built. It was clear to me despite my limited experience that the project was sure to face significant problems, and I reported this to CIDA officials [55]. To begin, I was shocked to learn that construction of the dam was initiated prior to any detailed investigation into erosion rates in the Calicanto River basin and the potential for rapid reservoir sedimentation. A study of erosion in the watershed had in fact been completed on CIDRE's behalf by Zimmerer [29] but it yielded only a rough estimation of erosion rates based on the universal soil loss equation [56,57] and, in any case, it was undertaken once construction of the dam was almost complete. As noted, eventually I was able to convince CIDA to commission a more detailed study on this issue. My report also highlighted other possible problems, such as: soil salinization, given that installation of a drainage system was ultimately removed as one of the components of Phase II; increased reliance on agrochemicals in the irrigation zone, due to the decline in water-borne sediment and nutrients; and the failure to address sewage treatment facilities in conjunction with Tarata's potable water supply component.

It is indeed puzzling that numerous senior professionals with much more experience than I never recognized the limitations and potential impacts of such a simplistic project design. Environmental sustainability had already emerged, supposedly, as a priority CIDA concern by the 1980s [58]. One can only hypothesize that despite the potential for negative impacts that must have been recognized by at least some of the parties involved, various pressures presented themselves to simply carry on with the program. Local NGOs and university research groups stood to benefit considerably from a project of this scale - in terms of operating funds, research funds, employment, and the like. The same can be said for the main Canadian executing agency, Club 2/3, the Montreal-based NGO. Canadian development NGOs receive, on average, almost half (47\%) of their funding from CIDA [2]. In the name of agency survival, therefore, they arguably have an inherent incentive to (a) carry on with implementing a project if awarded a contract, regardless of how ill-conceived it might be, and (b) to avoid criticizing CIDA or a particular project on its technical or other merits, and thereby biting the hand that feeds them, providing they even have the expertise to offer a valid critique. Even external consultants working as independent evaluators of a proposed or actual project may have an inherent interest in ensuring the project is approved or extended, given the desire to provide ongoing evaluation or advisory services once they have their foot in the door. In the case of the Laka Laka project, the consultancy that was hired to do the first technical and economic evaluation of the project [40] remained active for years thereafter as project monitors.

The implication that emerges from the above is that a greater effort must be made to remove the incentives that exist for approving or proceeding with a project even when it features important flaws and risks. One way to do this would be to ensure that consultants or other external actors engaged in project feasibility assessments and preliminary planning have little or nothing to gain from subsequent 
implementation. Another possible approach in this regard would be to ensure that CIDA or any such donor agency has enough staff members who are sufficiently trained and experienced to properly evaluate proposed and ongoing projects on their own. This should be more conducive to arriving at the most effective, equitable, and sustainable forms of international assistance, as the jobs of the parties involved would not depend upon a particular course of action.

In the mid-1990s, however, it was clear that CIDA had limited technical staff (but an abundance of administrative personnel) and thus it relied extensively on consultants for advice on project selection and evaluation. And among the agency's staff, technical or otherwise, most had little training in development and had spent limited time in developing countries. Very few had significant on-the-ground experience and the requisite, nuanced understanding of development challenges and issues. In essence, the agency's ability to select useful development initiatives and ensure their effective design was surprisingly weak. Many, more recent critiques of CIDA (e.g., [2,58-60]) indicate that the agency continues to suffer from these and many other problems.

According to Morrison ([58], p. 31), "Inadequate clarity within the agency on what constitutes good development - together with an intensely individualistic institutional culture - have both reflected and reinforced a lack of organizational and programming coherence". Black and Tiessen ([2], p. 207) point out that although CIDA has increasingly emphasized local ownership of development initiatives, 'ownership' is "targeted primarily at beneficiary governments and not at the NGOs working within these countries, nor the communities that are expected to benefit from the development projects". Perhaps this helps explain why, in the case of the Laka Laka project, local knowledge, technologies, and livelihood strategies were so disregarded, and why CIDRE was suddenly dumped from the project in 2005, at which time it was simply too late for it or any other party to address the project's problems in any meaningful way.

Another implication that emerges with the details of the project and its impacts is that the involvement of NGOs as primary executing agencies does not necessarily mean that local reality will be better explored and understood in assessing critical needs and designing a project to address these. As many others also have pointed out (e.g., [61-63]), it is commonly assumed that NGOs are more altruistic than government or business, more respectful of local knowledge and perspectives, and more effective at meeting local needs and promoting self-reliance. However, in many cases, including, apparently, this project, NGOs serve merely as instruments for the delivery of services based on a pre-determined set of inputs, outputs, and interventions [2]. Furthermore, the Laka Laka project shows that even relatively small-scale infrastructure projects executed by NGOs can generate significant environmental and socioeconomic changes.

Mabry and Cleveland ([44], p. 242) note that "In international agricultural development, the failure of projects planned and administered in ignorance of local systems as most have been, is legendary". It would seem that the Laka Laka Project rightfully deserves its place on this legendary list of failures.

\section{References and Notes}

1. Hettne, B. Development Theory and the Three Worlds; Longman: London, UK, 1990.

2. Black D.R.; Tiessen, R. The Canadian international development agency: New policies, old problems. Can. J. Dev. Stud. 2007, 28, 191-212. 
3. Preston, P.W. Development Theory: An Introduction; Blackwell: Oxford, UK, 1996.

4. Sachs, W. 'Poverty' - In need of a few distinctions. You can't measure wealth by cash alone. In Context 1993, Winter, 6; Available online: http://www.context.org/ICLIB/IC34/Sachs.htm (accessed on 15 September 2010).

5. Sachs, W. On the archaeology of the development idea, essay two. English translation by the Science, Technology, and Society Program, Pennsylvania State University, unpublished, undated. Cited in: Rural Development in the United States: Connecting Theory, Practice, and Possibilities; Galston, W.A., Baehler, K.J., Eds.; Island Press: Washington, DC/Covelo, CA, USA, 1995.

6. UNDP. Fast Facts: Poverty Reduction and UNDP; Available online: http://www.undp.org/ publications/fast-facts/FF-poverty.pdf (accessed on 12 May 2010).

7. United Nations Food and Agriculture Program (FAO). More People than Ever Are Victims of Hunger, 20 June 2009; Available online: http://www.fao.org/fileadmin/user_upload/newsroom/ docs/Press\%20release\%20june-en.pdf (accessed on 18 February 2010).

8. Bellemare, F. Memo to Pierre Racicot, Canadian International Development Agency (CIDA), Hull, Quebec, Canada, 25 October 1995.

9. Zimmerer, K.S. Rescaling irrigation in Latin America: The cultural images and political ecology of water resources. Ecumene 2000, 7, 150-175.

10. Céspedes, D.J. Plan de Riego: Epoca de Estiaje 2003. Unpublished report prepared by the technical manager of the Asociación de Regantes de Laka Laka, May 2003.

11. Flierman, M.; Den Hollander, M.; Van der Meer, S.; Ravenstijn, P. Laka Laka Problems: An Interdisciplinary Research to the Problems Related to the Laka Laka Water System in the Municipalities of Tarata and Arbieto in the Department of Cochabamba, Bolivia; Unpublished report, Centro Agua and MSPICM, Cochabamba, Bolivia, August 2003.

12. Servicio Nacional de Meteorología y Hidrología (SENAMHI). Normales 1961-1990 Precipitación; Available online: http://www.senamhi.gov.bo/meteorologia/datostpn.php (accessed on 6 December 2009).

13. Alcaldía de Arbieto. Plan de Desarrollo Municipal de Arbieto; Municipal Government of Arbieto: Cochabamba, Bolivia, 1988.

14. Instituto Nacional de Estadísticas de Bolivia. 2001 Census; Available online: http://www.ine.gov.bo/comunitaria/comunitariaVer.aspx?Depto=03\&Prov $=04 \&$ Seccion $=00$ (accessed on 26 November 2009).

15. Vargas, G. Gestión de agua en el municipio de Tarata; entre sistemas de riego independientes y la mancomunidad en la gestión de la presa. In Aguas y Municipios, Retos para la Gestión Municipal deAgua; Hoogendam, P., Ed.; PEIRAV: Cochabamba, Bolivia, 1999; pp. 87-116.

16. Zimmerer, K.S. Soil erosion and social (dis)courses in Cochabamba, Bolivia: Perceiving the nature of environmental degradation. Econ. Geogr. 1993, 69, 312-327.

17. Zimmerer, K.S. Environmental zonation and mountain agriculture in Peru and Bolivia. In Political Ecology: An Integrative Approach to Geography and Environment-Development Studies; Zimmerer, K.S., Bassett, T.J., Eds.; The Guilford Press: New York, NY, USA/London, UK, 2003; pp. 137-158.

18. Rengifo, G. El Suelo Agropecuario en las Culturas Andinas y en Occidente Moderno; PRATEC: Lima, Peru, 1994. 
19. Boer, B.; Castellón, R. Lameo, an indigenous method of soil conservation. ILEIA Newsletter, April 1996.

20. San Martín, J. Manejo de May'kas. Tecnologías campesinas de los Andes; Primer seminario taller Altiplánico de revaloración del conocimiento Andino: Oruro, Bolivia, 1988; pp. 106-114.

21. Club 2/3. Projet Laka Laka, Phase II; Rapport d'Etablissement du Projet: Revision. Club 2/3, Montreal, Quebec, Canada. Unpublished report prepared for the Canadian International Development Agency, September 1993.

22. Kohl, B. Stabilizing neoliberalism in Bolivia: Popular participation and privatization. Polit. Geogr. 2002, 21, 449-472.

23. Non-Governmental Organizations and the State in Latin America: Rethinking Roles in Sustainable Agricultural Development; Bebbington, A., Thiele, G., Eds.; Routledge: London, UK/New York, NY, USA, 1993.

24. Zimmerer, K.S. Nature under neoliberalism and beyond: Community-based resource management, environmental conservation, and farmer-and-food movements in Bolivia, 1985present.

In Beyond Neoliberalism in Latin America? Societies and Politics at the Crossroads; Burdick, J., Oxhorn, P., Roberts, K.M., Eds.; Palgrave Macmillan: New York, NY, USA, 2009; pp. 157-174.

25. Couture, M. Rapport de Fermeture de Projet Irrigation et Eau Potable Laka Laka; Projet d'action convergente \#192/16166. Unpublished consultant's report prepared for the Canadian International Development Agency, Hull, Quebec, Canada, May 1993.

26. Club 2/3. Projet Laka-Laka, Phase II: Diagnostic au 30 septembre 1994 et Proposition de Reformulation du Projet. Club 2/3, Montreal, Quebec, Canada. Unpublished report prepared for the Canadian International Development Agency, December 1994.

27. Soto Amurrio, C. Mayor, Arbieto, Cochabamba, Bolivia. Personal communication, 2 June 2005.

28. Zimmerer, K.S. Department of Geography, University of Wisconsin, Madison, WI, USA. Personal communication, 11 November 1993.

29. Zimmerer, K.S. Diagnostico: Uso de la Tierra y la Erosión de Suelos en la Cuenca del Rio Calicanto, Tarata. Report prepared for the Centro de Investigación y Desarrollo Regional (CIDRE), Cochabamba, Bolivia, 12 December 1991.

30. Northwest Hydraulic Consultants. An Assessment of Sedimentation of the Laka Laka Reservoir, Bolivia. Northwest Hydraulic Consultants Ltd, Vancouver, BC, Canada. Unpublished report prepared for the Canadian International Development Agency, May 1995.

31. Perez-Crespo, C.A. The social ecology of land degradation in central Bolivia. Presented at the Annual Meeting of the American Anthropological Association, Chicago, IL, USA, 20-24 November 1991.

32. Sedimentos en Microcuencas y Diseño de Obras de Almacenimiento; Informe de Investigación Aplicada \#17; Programa Nacional de Riego: Riego, Bolivia, 2001.

33. Escobar, M. Hydraulic Laboratory, Facultad de Ciencias y Tecnología, Universidad Mayor San Simon, Cochabamba, Bolivia. Personal communication, 31 May 2005.

34. Vasquez, E. Asociación de Regantes (Irrigator's Association) de Laka Laka, Arbieto, Cochabamba, Bolivia. Personal communication, 23 May 2005. 
35. Cespedes, J. Prefectura de Cochabamba, Cochabamba, Bolivia. Personal communication, 30 May 2005.

36. Cespedes, J. Prefectura de Cochabamba, Cochabamba, Bolivia. Personal communication, 22 June 2005.

37. Geomorphology and Groundwater; Brown, A.G., Ed.; Wiley: Chichester, NY, USA, 1995.

38. Blainey, J.B.; Pelletier, J.D. Infiltration on alluvial fans in arid environments: Influence of fan morphology. J. Geophys. Res. 2008, 113, F03008.

39. Bustamante, R.; Butterworth, J.; Flierman, M.; Herbas, D.; den Hollander, M.; van der Meer, S.; Ravenstijn, P.; Reynaga, M.; Zurita, G. Livelihoods in Conflict: Disputes over Water for Household-level Productive Uses in Tarata, Bolivia, 2004; Available online: http://www.irc.nl/ (accessed on 5 June 2006).

40. AFH International. Projet de Systeme d'Irrigation et Eau Potable-Laka-Laka, Bolivie: Rapport d'Evaluation Technique et Economique. Consultant's report to the Canadian International Development Agency; AFH International, Montreal, Quebec, Canada. Unpublished work, March 1989.

41. Hermogenes, L. Asociación de Regantes de Laka Laka, Arbieto, Cochabamba, Bolivia. Personal communication, 23 May 2005.

42. Education et Cooperation pour le Developpement; le Bulletin Institutionnel du Club 2/3; Club 2/3: Montreal, Quebec, Canada, 1993.

43. Zimmerer, K.S. The origins of Andean irrigation. Nature 1995, 378, 481-483.

44. Mabry, J.B.; Cleveland, D.A. The relevance of indigenous irrigation: A comparative analysis of sustainability. In Canals and Communities: Small Scale Irrigation Systems; Mabry, J.B., Ed.; University of Arizona Press: Tuscon, AZ, USA, 1996; pp. 227-260.

45. Trawick, P.B. Successfully governing the commons: Principles of social organization in an Andean irrigation system. Hum. Ecol. 2001, 29, 1-25.

46. Irrigation at High Altitudes: The Social Organization of Water Control Systems in the Andes; Mitchell, W.P., Guillet, D., Eds.; Society for Latin American Anthropology American Anthropological Association: Arlington, VI, USA, 1993.

47. Adams, W.M.; Anderson, D.M. Irrigation before development: Indigenous and induced change in agricultural water management in East Africa. Afr. Affairs 1988, 87, 519-535.

48. Bonine, M.E. From qanat to kort: Traditional irrigation technology and practices in central Iran. Iran 1982, 20, 145-159.

49. Medegama, J. State intervention in Sri Lanka's Village Rehabilitation Program. In Public Intervention in Farmer Managed Irrigation Systems; International Irrigation Management Institute: Digana, Sri Lanka, 1987; pp. 215-232.

50. Geertz, C. Organization of the Balinese Subak. In Irrigation and Agricultural Development in Asia: Perspectives from the Social Sciences; Coward, E.W., Jr., Ed.; Cornell University Press: Ithaca, NY, USA, 1980; pp. 70-90.

51. Dozier, E. The Pueblo Indians of North America; Holt, Rinehart and Winston: New York, NY, USA, 1970.

52. Brunhes, J. Les Differents Systemes d'Irrigation; Biblioteque Coloniale Internationale: Brussels, Belgium, 1908. 
53. Man and Water: The Social Sciences in Management of Water Resources; Douglas, J.L., Ed.; University of Kentucky Press: Lexington, KY, USA, 1974.

54. Mabry, J.B. The ethnology of local irrigation. In Canals and Communities: Small Scale Irrigation Systems; Mabry, J.B., Ed.; University of Arizona Press: Tucson, AZ, USA, 1996; pp. 3-20.

55. Shriar, A.J. Mission Report: Laka Laka Irrigation and Drinking Water Project, second draft. Unpublished report for the Canadian International Development Agency, 6 May 1992.

56. Wischmeier, W.H.; Smith, D.D. Predicting Rainfall Erosion Losses: A Guide to Conservation Planning; Agriculture Handbook No. 537; USDA/Science and Education Administration, US Government Printing Office: Washington, DC, USA, 1978.

57. Metodología Provisional para la Evaluación de la Degradación de los Suelos. United Nations Food and Agriculture Organization (FAO): Rome, Italy, 1980.

58. Morrison, D. Canadian aid: a mixed record and an uncertain future. In Transforming Development: Foreign Aid for a Changing World; Freedman, J., Ed.; University of Toronto Press: Toronto, Ontario, Canada, 2000; pp. 15-37.

59. Brown, S. 'Creating the world's best development agency'? Confusion and contradictions in CIDA's new policy blueprint. Can. J. Dev. Stud. 2007, 28, 213-228.

60. Schmitz, G. The verdict on aid effectiveness: Why the jury stays out. Int. J. 1996, 51, 287-313.

61. Korten, D. Getting to the 21st Century: Voluntary Action and the Global Agenda; Kumarian Press: West Hartford, CT, USA, 1990.

62. Beyond the Magic Bullet: NGO Performance and Accountability in the Post-Cold War World; Edwards, M., Hulme, D., Eds.; Kumarian Press: West Hartford, CT, USA, 1994.

63. Nauta, M. Ethnographic research in a non-governmental organization: Revealing strategic translations through an embedded tale. In Development Brokers and Translators: The Ethnography of Aid and Agencies; Lewis, D., Mosse, D. Eds.; Kumarian Press: West Hartford, CT, USA, 2006; pp. 173-193.

(C) 2010 by the authors; licensee MDPI, Basel, Switzerland. This article is an open access article distributed under the terms and conditions of the Creative Commons Attribution license (http://creativecommons.org/licenses/by/3.0/). 